\title{
The Limnology of a Mississippi River Alluvial Plain Oxbow Lake Following the Application of Conservation Practices
}

\author{
Scott Knight*, Robert Cullum, Richard Lizotte \\ USDA-ARS National Sedimentation Laboratory, Oxford, USA \\ Email: "scott.knight@ars.usda.gov
}

Received 20 March 2015; accepted 6 July 2015; published 9 July 2015

Copyright (C) 2015 by authors and Scientific Research Publishing Inc.

This work is licensed under the Creative Commons Attribution International License (CC BY). http://creativecommons.org/licenses/by/4.0/

\section{(c) (i) Open Access}

\begin{abstract}
From 1995 and 2011, Beasley Lake watershed near Indianola, MS, was subjected to a variety of conservation measures designed to reduce water velocity, erosion and discharge of sediment laden water. Water quality monitoring during the period indicated a number of long term trends and relationships between the parameters measured. Conservation practices reduced sediments and nutrients during the course of the study that resulted in increased Secchi visibility and chlorophyll $a$. Annual mean dissolved oxygen decreased slightly over time and was strongly dependent upon temperature, and weakly associated with varying salinity and $\mathrm{pH}$. Total phosphorus, ammonium nitrogen and nitrate nitrogen showed significant downward trends from 1995 through 2011. Chlorophyll $a$ concentration was significantly dependent upon total nitrogen but not phosphate, indicating nitrogen limiting conditions. Watershed based conservation practices significantly changed the long term water quality of Beasley Lake by reducing sediment and nutrients, increasing water clarity and boosting primary production as indicated by chlorophyll $a$.
\end{abstract}

\section{Keywords}

Chlorophyll, Nutrients, Non-Point Pollution, Water Quality, Watershed

\section{Introduction}

Despite significant financial investment in conservation practices and water quality protection, biodiversity continues to decline due to water quality and habitat degradation [1]-[5]. A recent national assessment rated about $42 \%$ of the nation's streams as having "poor" biological condition, with about one-third of total stream length desig-

"Corresponding author.

How to cite this paper: Knight, S., Cullum, R. and Lizotte, R. (2015) The Limnology of a Mississippi River Alluvial Plain Oxbow Lake Following the Application of Conservation Practices. Journal of Water Resource and Protection, 7, 707-714. 
nated as stressed by elevated nitrogen $(\mathrm{N})$ or phosphorus $(\mathrm{P})$ concentrations and about one-quarter impaired by riparian zone degradation or excess fine sediment in the streambed [6]. Recent national lakes assessment estimated $33 \%$ of lakes have poor lakeshore habitat and $20 \%$ have elevated nutrient levels, with agriculture cited as a leading source of impairment [7]. Fresh water bodies are experiencing declines in biodiversity as much as five times more rapidly than those in the most affected terrestrial ecosystems [8]. Future influences on environmental quality include synergistic effects of climate change, biofuel production, increased human population and exotic species. In recent decades, major strides have been made in implementing soil conservation measures, but in many agricultural landscapes, water quality issues remain unsolved [9]. Off-site and downstream impacts of agricultural water pollution continue to raise concerns, most notably marine dead zones linked to excess $\mathbf{N}$ and $\mathrm{P}$ [10] [11]. Rivers and natural lakes within cultivated floodplains also experience chronic hypoxia [12]. New and improved technology is needed to address these issues in support of Federal mandates under the Clean Water Act of 1972, the Food, Conservation, and Energy Act of 2008, and the Mississippi River Basin Healthy Watersheds Initiative (MRBI).

One of the most intensively farmed agricultural areas of the United States is the southern portion of the Mississippi River Alluvial Plain, an 11 million hectares area locally referred to as the Mississippi Delta. This alluvial plain region is a narrow strip on both sides of the Mississippi River, widening in some places to approximately 160 kilometers, that extends over 1100 kilometers from southeastern Missouri to the Gulf of Mexico. Agricultural activities in the Delta differ significantly from those in other regions such as the mid-western United States [13]. The humid sub-tropical climate in the Delta allows a different array of crops and cultural practices than those common in other areas of the United States. These factors, in combination with high regional rainfall amounts, can increase the chances for soil erosion and chemical movement within Delta watersheds.

Agricultural activities are considered, by some, to be a major source of nonpoint source pollution in the United States. Examples of nonpoint source pollution have been documented in various agricultural regions like the Midwest [14]. Nonpoint source pollutants include sediment [15], pesticides and nutrients [16]-[18]. Legislation such as the Clean Water Act recognizes agricultural Best Management Practices (BMPs) as methods to reduce nonpoint source pollution. BMPs are typically implemented on farms on a voluntary basis with funding provided through cost-share programs if available. However, since the late 1980's, legislation such as reauthorizations of the Clean Water Act and the Farm Bill began to contain language that implied the mandatory use of BMPs in agricultural communities to reduce nonpoint source pollution.

Delta lakes, long known for their productivity and recreational value [19], have not escaped the detrimental effects of soil erosion. Their popularity as recreational resources has decreased as water quality and fisheries have declined [20]. Cooper and Knight [21] have attributed these declines, in part, to soil erosion and sedimentation. Detrimental impacts on stream and lake water quality due to erosion and sedimentation have been well documented [22] [23].

Oxbow lakes are remnants of meandering floodplain rivers that have been cut off and physically isolated from their respective main river channels. Because of this isolated condition, changes begin to occur in the physical and chemical characteristics of the lake basin and in the floral and faunal assemblages. Over time allochthonous organic materials derived from previous connections with the floodplain river ecosystem are processed and energetically depleted. Isolated oxbow lakes in agricultural regions tend to become less heterotrophic and more autotrophic, becoming closed entities within themselves, functioning similarly to farm ponds and other small impoundments.

If suspended sediment concentrations are low enough to provide suitable light penetration, oxbow lakes provide conditions conducive to photosynthesis, primarily via phytoplankton, and may support a sustainable sport fishery. However, agricultural practices often result in soil erosion that can lead to increased turbidity in the oxbow lakes and subsequent inhibition of photosynthesis. Turbidity in oxbow lakes can be persistent in areas having soils with high clay content. Although nutrients such as phosphorus are commonly associated with delta soils and isolated oxbow lakes tend that to load nutrients, these systems may become energy starved and very unproductive due to lack of light penetration.

\section{Materials and Methods}

Beasley Lake Watershed was a component of the Mississippi Delta Management Systems Evaluation Area (MDMSEA) from 1994-2004 and was later included as one of 14 USDA Conservation Effects Assessment Project 
(CEAP) benchmark watersheds [24]. As such, the watershed has produced a significant long-term database of best management practices (BMPs) from 1994-2011. This study was conducted on Beasley Lake located south of Indianola, MS, in Sunflower County in the lower Mississippi River drainage basin. Beasley Lake is a 16 ha oxbow with a large wooded riparian zone located in a 915 ha watershed. During the initial years of the study (19941996), Beasley Lake watershed (BLW) was farmed using conventional tillage to grow cotton (Gossypium hirsutum L.) and soybeans (Glycine max [L.] Merr). Over the course of the study the watershed received a variety of conservation management practices designed to reduce water velocity, erosion, and discharge of sediment-laden water into the lake; thus, reducing nonpoint source pollutants entering the lake [25]. From 1994-2011, crops produced in BLW included cotton, corn (Zea mays L.), and soybean, approximately half irrigated with center pivot systems with the remainder dryland. Seven independent BMPs have been implemented at BLW. From 1994-1996, three structural edge-of-field BMPs were implemented: vegetative filter strips comprised of switchgrass (Panicum virgatum L.) or fescue (Festuca arundinacea Schreb.); pipes with slotted board risers for water impoundment during the fallow season; or pipes with slotted inlets to impede water flow positioned at outlets of sub-drainage areas. Beginning in 2001, much of the cropland was converted to reduced tillage with winter cover crops. From 2003-2004, 12.4\% (114 ha) of the arable land was removed from row-crop production and planted in trees under Conservation Reserve Program (CRP) implementation. In 2006, 4 - 5 ha of arable land along the southern lake shoreline was removed from row-crop production and converted to vegetative buffer habitat to attract northern bobwhite quail (Colinus virginianus) [26]. A constructed wetland and a two-cell sediment basin, respectively, were established in 2003 and 2010, respectively.

Water quality was measured from February 1995 through August 2011. Water sampling sites were located at three locations; one in the middle of the lake and one at each distal end. Surface water was collected at each site at the depth of approximately $0.25 \mathrm{~m}$. Automated water quality monitoring equipment was used to obtain biweekly measurements of temperature, $\mathrm{pH}$, dissolved oxygen and conductivity. Surface water was sampled biweekly for total, suspended, and dissolved solids, total phosphorus, filterable ortho-phosphate, total nitrogen, ammonium nitrogen and nitrate nitrogen, chlorophyll, coliform and enterococci bacterial counts and Secchi visibility. Additional and more specific details of sampling regimes, physical and chemical parameters measured, and analysis procedures for the project varied with the different aspects of the project and are in [27].

Analytical and chemical methods were based on procedures from [28]. Calculation of means and statistical analysis (linear regressions or correlations) were completed using SigmaStat for Windows version 2.03 statistical software. All parameters were tested for differences at the $5 \%$ level of significance.

\section{Results and Discussion}

\subsection{Trends through Time}

An examination of the data showed several trends over time. Dissolved oxygen concentrations decreased slightly over time while $\mathrm{pH}$ and salinity exhibited slight increases (Figure 1) While the trends were statistically significant the standard coefficients were very low; -0.141 for dissolved oxygen, 0.247 for $\mathrm{pH}$ and 0.280 for salinity. However, there were relatively strong positive correlations between conductivity (correlation coefficient $=r=$ $0.681)$, salinity $(r=0.356)$ and dissolved solids $(r=0.694)$ with time. This is reasonable since dissolved solids are primarily salts which will affect salinity concentrations which in turn has a positive effect on conductivity.

Suspended and total solids decreased significantly over the course of the study. Total solids decreased 65\% from an annual mean high of $592 \mathrm{mg} / \mathrm{L}$ in 1996 to an annual mean low of 82 in 2008. Suspended solids, the major component of total solids also showed significant downward trends with time $(\mathrm{r}=-0.455)$. Both Secchi depth and chlorophyll $a$ concentrations increased as suspended solids decreased (Figure 2). The significant inverse relationship $(r=-0.544)$ between Secchi visibility and total solids is expected since suspended sediment will reduce visibility (Figure 3). The decrease over time was likely due to the application of conservation practices designed to reduce sediment in agricultural runoff. Total phosphorus $(r=-0.429)$, ammonium nitrogen $(r=-0.421)$ and nitrate nitrogen $(r=-0.295)$ showed significant downward trends during the course of the study. Figure 4 shows decreasing monthly mean total phosphate and nitrate over time with an increasing concentration of monthly mean chlorophyll $a$ (Figure 4). Trends are more easily seen by plotting monthly mean total phosphate, nitrate and chlorophyll $a$ by year (Figure 5). Annual mean chlorophyll $a$ significantly increased from 1995 through 2011 ( $\mathrm{r}=$ 0.726). 


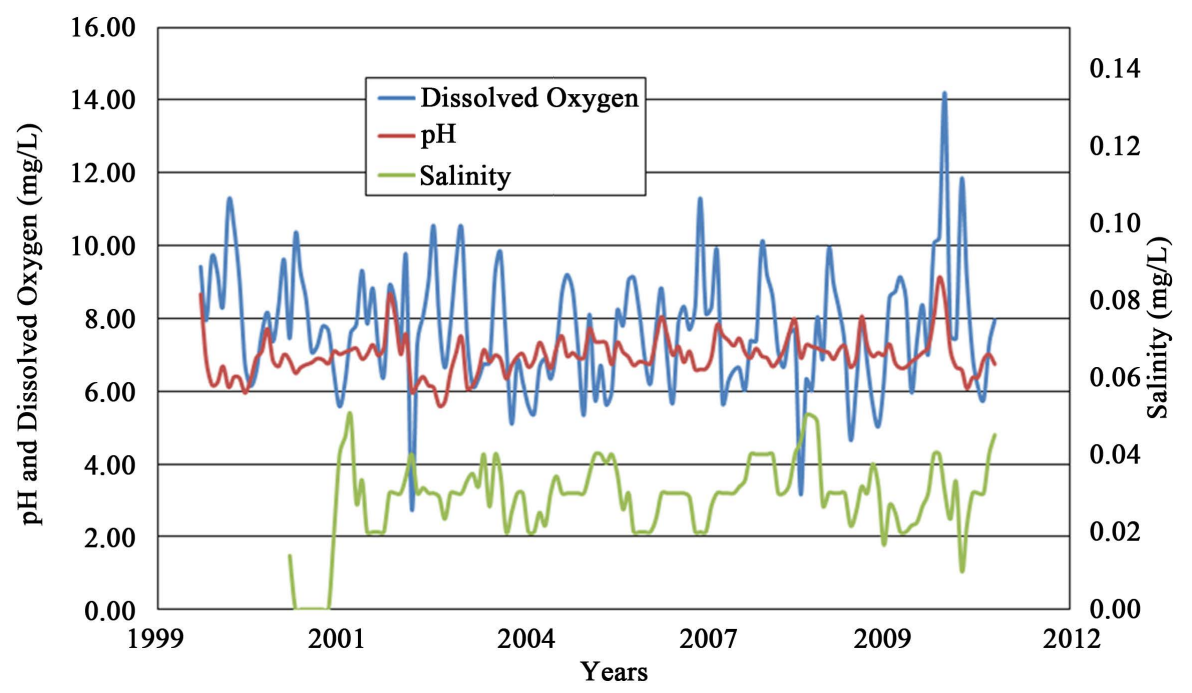

Figure 1. Monthly pH, dissolved oxygen concentration and salinity from 1999 through 2011 from Beasley Lake.

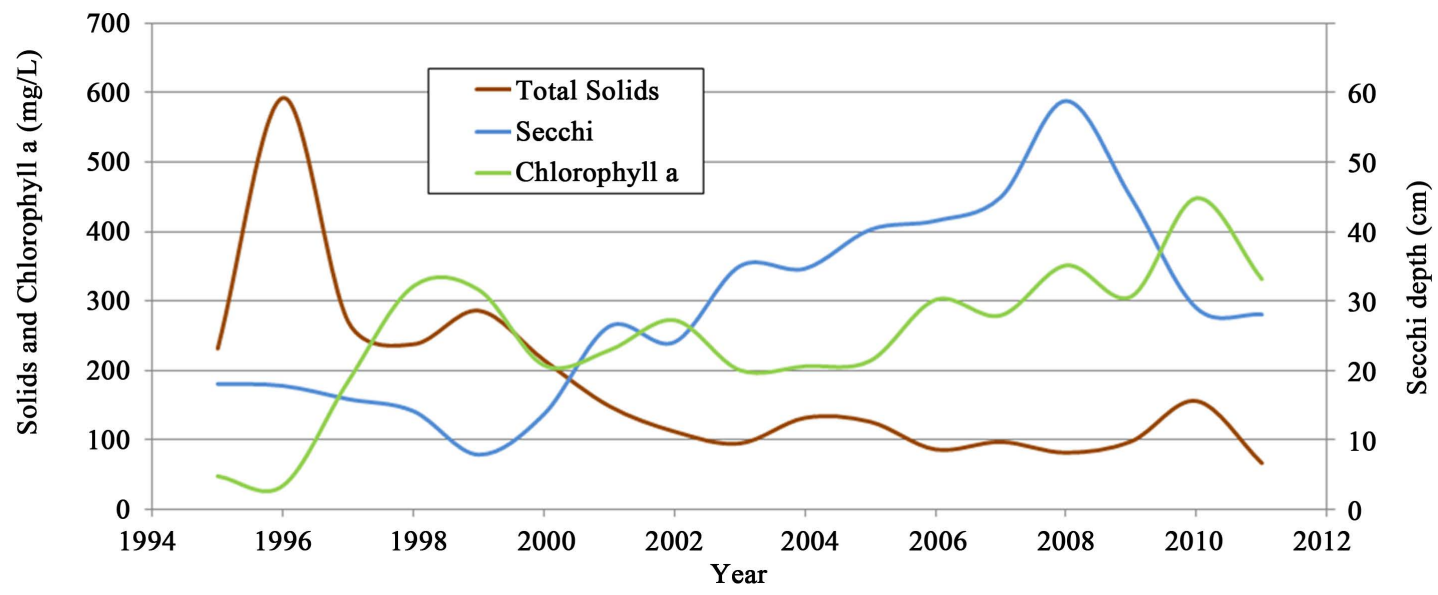

Figure 2. Annual means for total solids, Secchi and chlorophyll $a$ in Beasley Lake from 1995 through 2011.

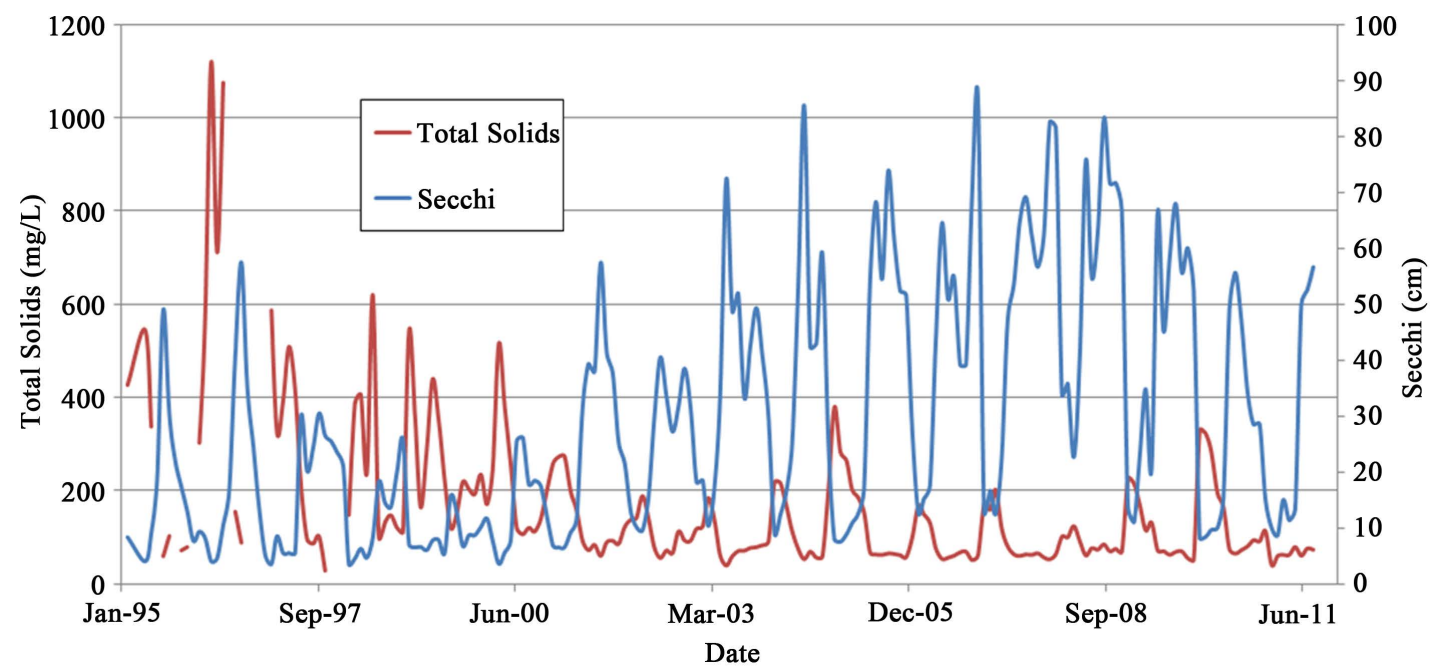

Figure 3. Monthly mean Secchi depth and total solids concentrations for Beasley Lake from January 1995 through June 2011. 


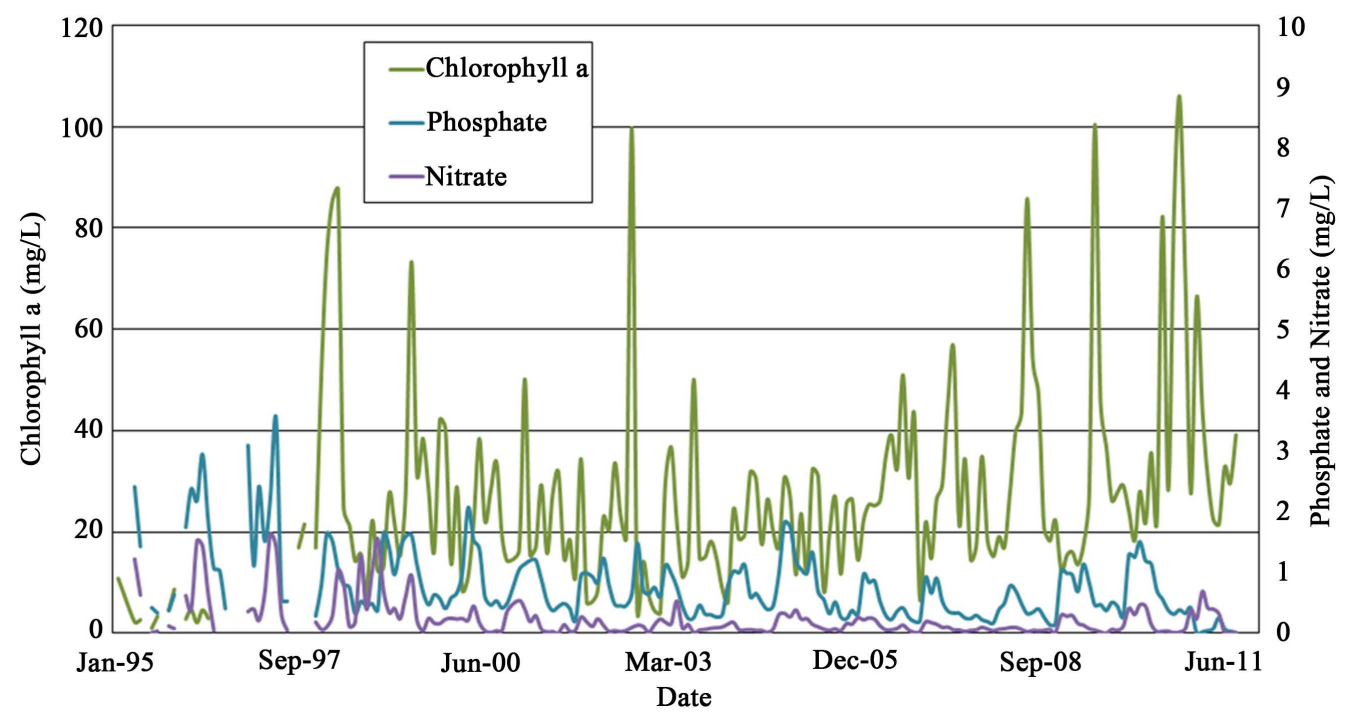

Figure 4. Monthly mean chlorophyll a, phosphate and nitrate concentrations for Beasley Lake from 1995 through 2011.

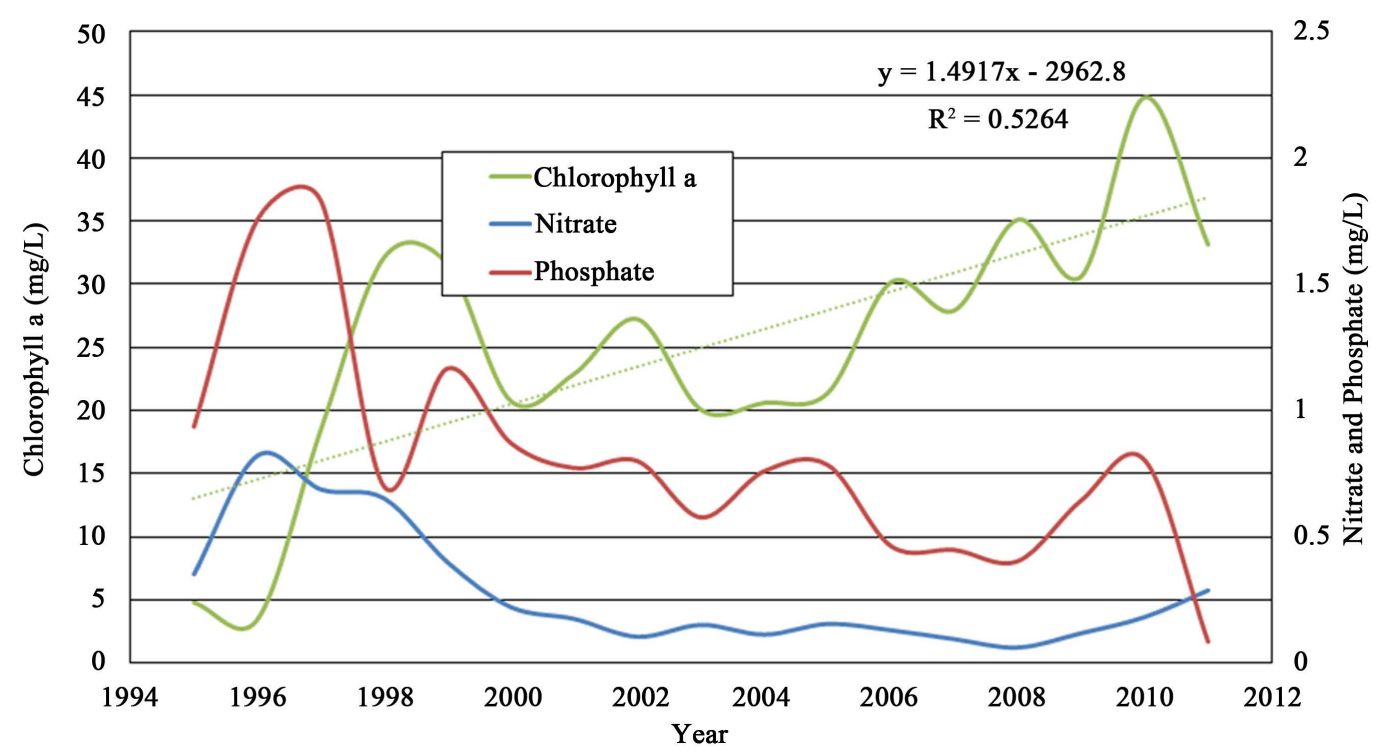

Figure 5. Annual mean chlorophyll a, nitrate and phosphate concentrations for Beasley Lake from 1995 through 2011.

\subsection{Relationships between Parameters}

The temperature, conductivity and salinity data indicated positive significance among one another. As temperatures increased during any given year evaporation likely increased the salt concentrations in the lake. The correlation coefficient for temperature and conductivity was 0.802 and for temperature and salinity was 0.694 . As one might expect dissolved oxygen was dependent upon temperature $(\mathrm{r}=-0.572)$ and varied seasonally. Salinity was significantly but weakly related to dissolved oxygen concentrations (Figure 6), as dissolved oxygen increased salinity tended to decrease. This finding is consistent with the relationship between salinity and dissolved oxygen as reported by [29]. Conversely, as dissolved oxygen increased, pH also increased. It is likely that as phytoplankton removed carbon dioxide from the water column and produced oxygen, carbonates accumulated, hydrolyzed, and raised $\mathrm{pH}$ [29]. Analysis of chlorophyll $a$ and phosphorus showed no significant relationships among chlorophyll $a$, total phosphate, and ortho-phosphate, however there was a significant positive relationship between total Kjeldhal nitrogen and total nitrogen (Figure 7). While phosphorus is most commonly the limiting nutrient of fresh water, nitrogen can be limiting and this may be the case in Beasley Lake. 


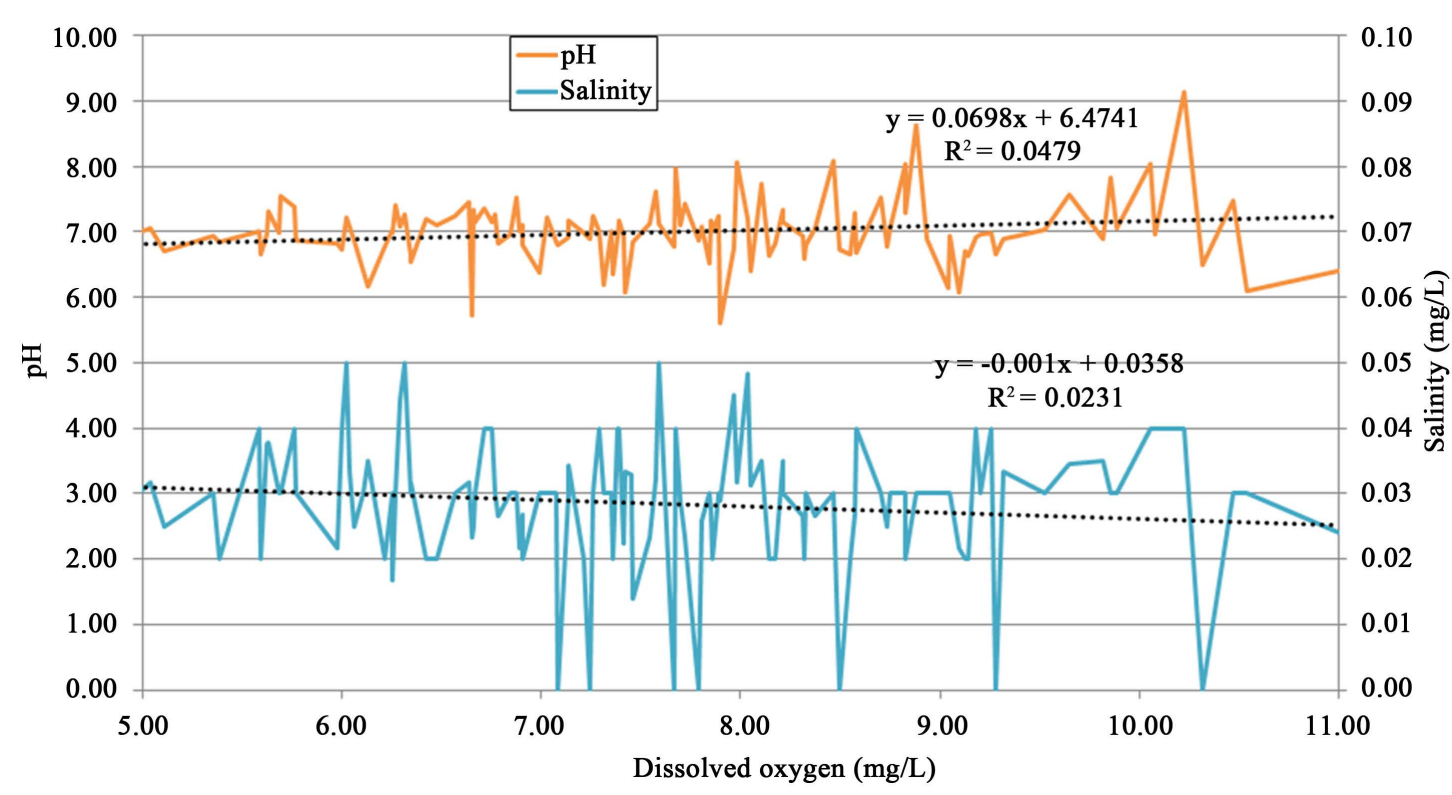

Figure 6. Monthly mean $\mathrm{pH}$ and salinity plotted against dissolved oxygen concentration for Beasley Lake.

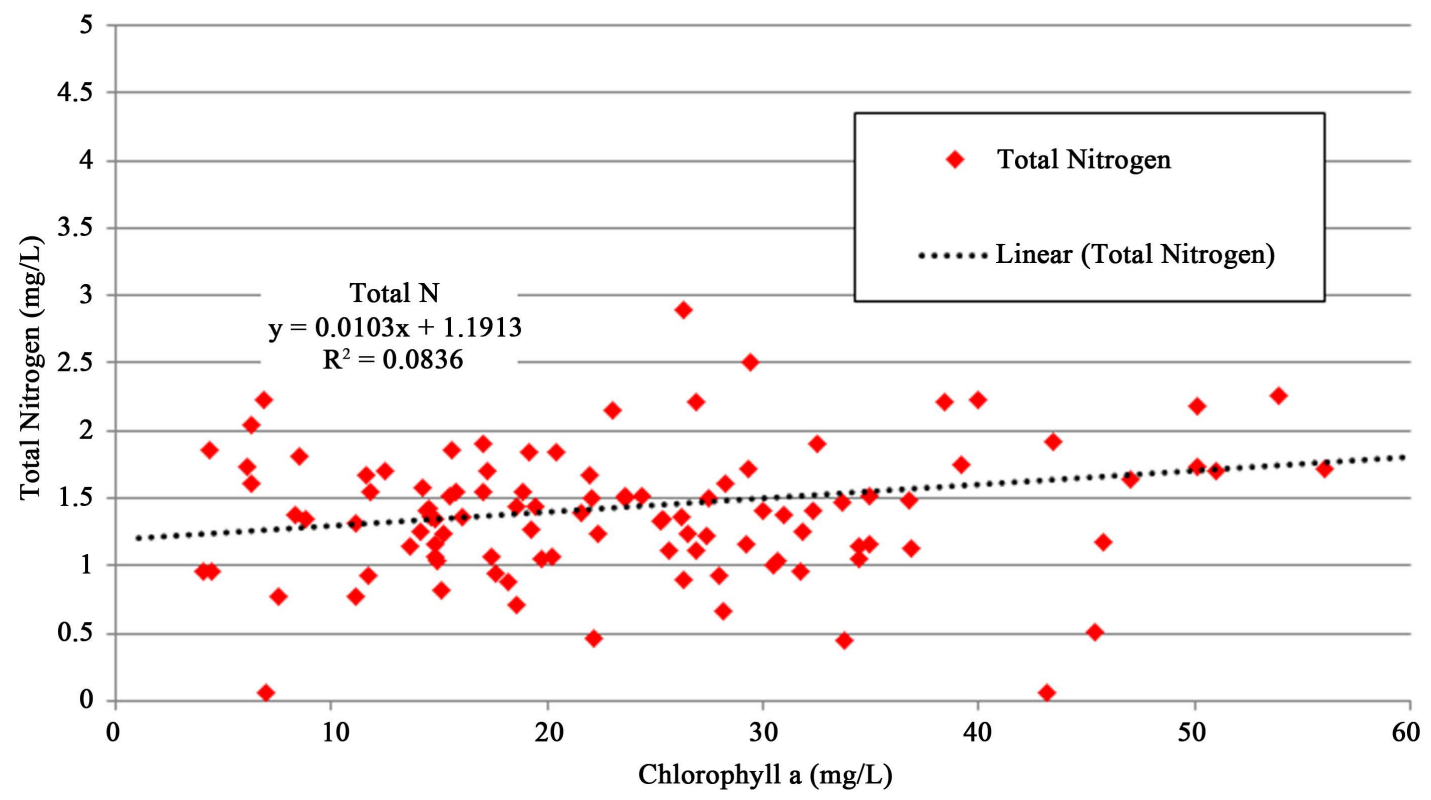

Figure 7. Mean monthly total nitrogen versus mean monthly chlorophyll $a$ for Beasley Lake from 1995 through 2011.

\section{Conclusion}

Conservation practices effectively reduced sediment and nutrient entering Beasley Lake via agricultural runoff during the course of the study. In response, Secchi visibility and chlorophyll $a$ increased over time. Annual mean dissolved oxygen decreased slightly over time and was strongly dependent upon temperature, and weakly associated with varying salinity and $\mathrm{pH}$. Total phosphorus, ammonium nitrogen and nitrate nitrogen showed significant downward trends from 1995 through 2011. Chlorophyll $a$ increased during the study period and was significantly dependent upon total nitrogen and total Kjeldhal nitrogen but not phosphate indicating nitrogen limiting conditions. This research demonstrates the effectiveness of watershed based conservation practices in reducing sediment and nutrients, increasing water clarity and boosting primary production as indicated by chlorophyll $a$. Further it provides insight into the dynamics of limnological parameters of shallow oxbow lakes. 


\section{References}

[1] Ricciardi, A. and Rasmussen, J.B. (1999) Extinction Rates of North American Freshwater Fauna. Conservation Biology, 13, 1220-1222. http://dx.doi.org/10.1046/j.1523-1739.1999.98380.x

[2] Warren Jr., M.L., Burr, B.M., Walsh, S.J., Bart Jr., H.L., Cashner, R.C., Etnier, D.A., Freeman, B.J., Kuhajda, B.R., Mayden, R.L., Robison, H.W., Ross, S.T. and Starnes, W.C. (2000) Diversity, Distribution, and Conservation Status of the Native Freshwater Fishes of the Southern United States. Fisheries, 24, 7-31. http://dx.doi.org/10.1577/1548-8446(2000)025<0007:DDACSO>2.0.CO;2

[3] Karr, J.R., Allan, J.D. and Benke, A.C. (2000) River conservation in the United States and Canada. In: Boon, P.J., Davies, B.R. and Petts, G.E., Eds., Global Perspectives on River Conservation, Science, Policy, and Practice, John Wiley \& Sons Ltd., Chichester, 3-39.

[4] Aarts, B.G.W., Van Den Brink, W.B. and Nienhuis, P.H. (2004) Habitat Loss as the Main Cause of the Slow Recovery of Fish Faunas of Regulated Large Rivers in Europe: The Transversal Floodplain Gradient. River Research and Applications, 20, 3-23. http://dx.doi.org/10.1002/rra.720

[5] Shields Jr., F.D., Knight, S.S., Lizotte, R.E. and Wren, D.G. (2010) Floodplain River Backwater Restoration: A Case Study. Proceedings of the 9th Federal Interagency Sedimentation Conference, Joint Federal Interagency Conference Organizing Committee, Washington DC, CD-ROM.

[6] Paulsen, S.G., Mayio, A., Peck, D.V., Stoddard, J.L., Tarquinio, E., Holdsworth, S.M., Van Sickle, J., Yuan, L.L., Hawkins, C.P., Herlihy, A.T., Kaufmann, P.R., Barbour, M.T., Larsen, D.P. and Olsen, A.R. (2008) Condition of Stream Ecosystems in the US: An Overview of the First National Assessment. Journal of the North American Benthological Society, 27, 812-821. http://dx.doi.org/10.1899/08-098.1

[7] USEPA (2009) National Lakes Assessment: A Collaborative Survey of the National's Lakes. EPA 841-R-09-001 USEPA, Office of Water and Office of Research and Development, Washington DC, 118 p.

[8] Dudgeon, D., Arthington, A.H., Gessner, M.O., Kawabata, Z.I., Knowler, D.J., Lévêque, C., Naiman, R.J., Prieur-Richard, A.H., Soto, D., Stiassny, M.L.J. and Sullivan, C.A. (2006) Freshwater Biodiversity: Importance, Threats, Status and Conservation Challenges. Biological Reviews, 81, 163-182. http://dx.doi.org/10.1017/s1464793105006950

[9] Locke, M.A., Tyler, D.D. and Gaston, L.A. (2010) Soil and Water Conservation in the Mid-South United States: Lessons Learned and a Look to the Future. In: Zobeck, T.M. and Schillinger, W.F., Eds., Soil and Water Conservation Advances in the United States, SSSA Special Publication 60, SSSA, Madison, WI, 201-236.

[10] Diaz, R.J. and Rosenberg, R. (2008) Spreading Dead Zones and Consequences for Marine Ecosystems. Science, 321, 926-929. http://dx.doi.org/10.1126/science.1156401

[11] Bianchi, T.S., DiMarco, S.F., Cowan, J.H., Hetland, R.D., Chapman, P., Day, J.W. and Allison, M.A. (2010) The Science of Hypoxia in the Northern Gulf of Mexico: A Review. Science of The Total Environment, 408, 1471-1484. http://dx.doi.org/10.1016/j.scitotenv.2009.11.047

[12] Shields Jr., F.D. and Knight, S.S. (2010) Pre-Restoration Assessment, Big Sunflower River, Mississippi: Where to Begin? Proceedings of the 2010 World Environmental and Water Resources Congress, Reston, VA, 16-20 May 2010, 1777-1787. http://dx.doi.org/10.1061/41114(371)186

[13] Knight, S.S., Rebich, R.A., Smith Jr., S., Schreiber, J.D., Locke, M.A. and Hanks, J.E. (2002) The Mississippi Delta Management Systems Evaluation Area Project. Proceedings of the Sixth International Conference on Diffuse Pollution, Amsterdam, 30 September-4 October 2002, 471-478.

[14] Pereira, W.E. and Hostettler, F.D. (1993) Nonpoint Source Contamination of the Mississippi River and Its Tributaries by Herbicides. Environmental Science and Technology, 27, 1542-1552. http://dx.doi.org/10.1021/es00045a008

[15] Duda, A.M. and Johnson, R.J. (1985) Cost-Effective Targeting of Agricultural Non-Point Source Pollution Controls. Journal of Soil and Water Conservation, 40, 103.

[16] Mueller, D.K., Hamilton, P.A., Helsel, D.R., Hitt, K.J. and Ruddy, B.C. (1995) Nutrients in Ground Water and Surface Water of the United States-An Analysis of Data through 1992. US Geological Survey Water-Resources Investigations Report 95-4031, 74 p.

[17] Meade, R.H., Ed. (1995) Contaminants in the Mississippi River, 1987-1992. US Geological Survey Circular 1133, 140 p.

[18] Gilliom, R.J., Alexander, R.B. and Smith, R.A. (1985) Pesticides in the Nation's Rivers, 1975-1980, and Implications for Future Monitoring. US Geological Survey Water-Supply Paper 2271, 26 p.

[19] Cooper, C.M., Bacon, E.J. and Ritchie, J.C. (1983) Biological Cycles in Lake Chicot, Arkansas. Proceedings of the Arkansas Lakes Symposium: Limnological Studies of Lake Chicot, Lake Chicot, 4-6 October 1983, 48-61.

[20] Coleman, F.W. (1969) State-Wide Lake and Stream Survey. Completion Report Project F-8-R, Fisheries Division Mississippi Game and Fish Commission. 
[21] Cooper, C.M. and Knight Jr., L.A. (1978) Fishes and Water Quality Conditions in Six-Mile Lake, Bear Creek Drainage, Mississippi. Proceedings of the Annual Meeting of the Mississippi Chapter American Fisheries Society, 2, 27-36.

[22] Knight, S.S., Starks, P.J., Hardegree, S. and Weltz, M. (1994) Scientific Challenges and Opportunities in Wetland and Riparian Research. Proceedings of the ARS Conference on. Hydrology, Denver, 13-15 September 1993, 147-162.

[23] Waters, T.R. (1995) Sediment in Streams: Sources, Biological Effects, and Control. American Fisheries Society Monograph 7, $251 \mathrm{p}$.

[24] Locke, M.A. (2004) Mississippi Delta Management Systems Evaluation Areas: Overview of Water Quality Issues on a Watershed Scale. In: Nett, M.T., Locke, M.A. and Pennington, D.A., Eds., Water Quality Assessments in the Mississippi Delta: Regional Solutions, National Scope, ACS Symposium Series 877, 1-15. http://dx.doi.org/10.1021/bk-2004-0877.ch001

[25] Cullum, R.F., Locke, M.A. and Knight, S.S. (2010) Effects of Conservation Reserve Program on Runoff and Lake Water Quality in an Oxbow Lake Watershed. Journal of International Environmental Application and Science, 5, 318328.

[26] Locke, M.A., Knight, S.S., Smith, S., Cullum, R.F., Zablotowicz, R.M., Yuan, Y. and Bingner, R.L. (2008) Environmental Quality Research in the Beasley Lake Watershed, 1995 to 2007: Succession from Conventional to Conservation Practices. Journal of Soil and Water Conservation, 63, 430-442. http://dx.doi.org/10.2489/jswc.63.6.430

[27] Rebich, R.A. and Knight, S.S., Eds. (2001) Mississippi Delta Management Systems Evaluation Areas Project, 1995-99. Mississippi Agricultural and Forestry Experiment Station Bulletin, 222 p.

[28] American Public Health Association (1998) Standard Methods for the Examination of Water and Waste Water. 20th Edition, APHA, Washington DC, 1056 p.

[29] Boyd, C.E. (1990) Water Quality in Warmwater Fish Ponds. Auburn University Agricultural Experiment Station, Auburn, AL, 359 p. 